\title{
POSSIBLE TOXIC EFFECTS OF BENZODIAZEPINES;
}

\section{At therapeutic doses due to drug-drug interactions in hospitalized patients}

\section{Dr. Syed Talat Iqbal, Dr. Zainab Batool, Dr. Sajid Mehmood}

ABSTRACT... Introduction: Benzodiazepines and its derivatives are used widely as anxiolytics, hypnotics, seizure control and as muscle relaxants. Design: The prescriptions of 270 patients were evaluated for moderate to severe drug interactions using drug interaction detection software. Setting: Teaching hospital in Gujrat, Pakistan. Objective: This study is used to evaluate the possible toxic effects of benzodiazepine related drug-drug interactions in prescriptions of indoor patients. Material \& Methods: The prescriptions were processed through a software program named, The Medical Letter Adverse Drug Interaction program. The randomly collected patient chart profiles included both male and female patients ranging from age of few months old children to old aged patients. Result: Out of 270 patients medication charts 210 medication charts were having at least one or more drug interactions ranging from moderate to severe. Out of 80 interacting drug combinations found, 15 were benzodiazepine related drug interactions. So, percentage of benzodiazepines related drug interactions was 18.75\%.Moreover, the data also showed that the percentage of DDIs increases as the prescription size increases. Our results indicate that hospitalized patients in Pakistan are at risk of ADRs caused by potential DDIs. Moreover, there are chances that the safe therapeutic doses of benzodiazepines may become toxic or ineffective due to drug-drug interactions and polypharmacy. Conclusions: So, the use of DDIs detection software programs in hospitals and pharmacies should be promoted in order to minimize drugs especially benzodiazepines related injuries and to ensure patient safety.

Key words: Benzodiazepines, Drug-drug interactions, Prescriptions, Pakistan.

Article Citation

lqbal ST, Batool Z, Mehmood S. Possible toxic effects of benzodiazepines; At therapeutic doses due to drud-drug interactions in hospitalized patients. Professional Med J 2013;20(2): 284-289.

\section{INTRODUCTION}

Benzodiazepines shares parallel neuropharmacologic characteristics together with sedation, sleep induction, anxiety reduction, muscle relaxation and anticonvulsant effects ${ }^{1}$.

In medical and psychiatric practice benzodiazepines and its derivatives are used widely as anxiolytics, hypnotics, seizure control and as muscle relaxants. During past two decades, the use of benzodiazepines has been widely increased. Whenever a patient is treated with two or more than two drugs at the same time, there are chances that the drugs may interact in such way that can alter their pharmacokinetic and pharmakodynamic parameters. This can result in increased or decreased drug concentrations resulting in drug toxicity or ineffective treatment ${ }^{1,2}$. There may be multiple drug interactions in a single prescription but only few are clinically important to be considered and monitored $^{3,5}$. Polypharmacy is associated with multiple DDIs, prescription errors, ADRs and sometimes ineffective treatment ${ }^{6,}{ }^{7}$. The more pronounced adverse effects of this class of drugs reaction has become a great matter of discussion for the clinical studies. The etiology of unnecessary medicine good effects has concerned assessment of drug pharmacokinetics and pharmacodynamics ${ }^{4}$. Blood loss owing to oral anticoagulants, gastropathy and hypoglycemia from diabetes treatment linked with non-steroidal anti-inflammatory drugs have been recognized in epidemiological studies as recurrent unpleasant drug reactions in aged persons ${ }^{8,9}$. As polypharmacy is widespread, the possible for unpleasant drug reactions has amplified for each drug group $^{10-12}$.

Only $3 \%$ of all hospital admissions are the risk of DDIs ${ }^{8-}$ ${ }^{12}$. When physicians cannot avoid the use of multiple drugs in case of serious patients then risk benefit ratios are considered, also considering the availability of alternatives. Drug-drug interactions are important to consider while using the drugs with narrow 
therapeutic ratios and especially when patient is renally or hepatically compromised, too young or too old and when multiple drugs are being administered at the same time to the same patient. As the number of drugs increases in prescriptions, it is more suitable to use drug interaction detection software programs to ensure the patient safety ${ }^{13,14}$.

In Pakistan and many other countries, there is no trend to evaluate the prescriptions for drug interactions either manually or by screening programs for DDIs detection. Almost all patient medication charts are hand written. Patients are at great risk of ADRS due to DDIs. Although issues like primary health care and pharmaceutical care are always in talk but the area of study like drug interactions has not been given any importance in Pakistan and many other countries until now ${ }^{15-18}$.

\section{OBJECTIVE OF STUDY}

The objective of the study was to evaluate the toxic effects of benzodiazepines related potential drug-drug interactions in indoor patients in a teaching hospital in Pakistan. The secondary objective was to evaluate the frequency of benzodiazepine related drug-drug interactions in hospitalized patients.

\section{METHODS}

Patient medication charts hospitalized in different wards including male medical ward, female medical ward, gynae ward, children ward, emergency ward and TB ward of a teaching hospital in Gujrat, Pakistan were collected over a period of 3 months. The medication charts were picked randomly including male, female, young and old patients. The prescriptions were processed in THE MEDICAL LETTER ADVERSE DRUG INTERACTION PROGRAM. The drug interactions found related to benzodiazepines were separated and their percentage was calculated in relation to total number of interacting combinations found using Microsoft excel. The information was collected with the consent of hospital authorities and it included name, age, sex, diagnosis, patient history, list of medications and doses. The detected DDIs were cross-over checked manually for enough published scientific data to support our results ${ }^{19}$. Major DDIs include those which can cause serious harm to the patient if goes unchecked while moderate include those which are documented DDIs but are not of serious nature and can be minimized by just monitoring the patient for $\mathrm{ADRs}^{20}$. The insignificant drug interactions were not considered. Only major and moderate DDIs were further analyzed in Microsoft Excel.

\section{RESULTS \& DISCUSSION}

Each prescription on average contains 5 to 6 medications. Out of these 270 prescriptions 210 i.e. $77 \%$ prescriptions were containing one or more drug interactions while 60 i.e. $23 \%$ prescriptions were having not even a single minor drug interaction. (Figure-1). Total 80 interacting combinations were found in 270 prescriptions. Out of these 80 interacting combinations 15 combinations were benzodiazepine related i.e. 18.75\% (Figure-2).The results also showed that as the number of drugs in a prescription increases, the frequency of drug interactions increases. Drug interactions related to benzodiazepines are also shown in table-I. The results indicate benzodiazepine toxicity problems that can result due to potential drug-drug interactions and lack of prescription monitoring programs. If this study is conducted on large scale, more reliable results can be obtained. Medications when used in combination with other drugs like benzodiazepines must be selected carefully to avoid resulting toxicity and prescription errors $^{21-27}$.

This indicates that the indoor patients in Pakistan hospitals who are under treatment with more than 4 or 5 drugs are at the risk of moderate to severe drug interactions. These interactions may be life threatening and require close monitoring in order to ensure patient safety, or they may be moderate and can exacerbate 


\begin{tabular}{|c|c|c|c|}
\hline DRUG COMBINATION & $\begin{array}{l}\text { TYPE/MECHANISM OF } \\
\text { INTERNATIONAL }\end{array}$ & POTENTIAL ADVERSE EFFECTS & RECOMMENDATION \\
\hline $\begin{array}{c}\text { Ranitidine } \\
\text { (Antihistamines, H2-blockers) } \\
\text { Valium (Benzodiazepines) }\end{array}$ & $\begin{array}{l}\text { Pharmakokinetic } \\
\text { (decreased metabolism) } \\
\text { (altered absorption) }\end{array}$ & Possible benzodiazepine toxicity & $\begin{array}{l}\text { Monitor clinical status; oxazepam, } \\
\text { lorazepam, and temazepam do not } \\
\text { interact; famotidine, and possibly } \\
\text { nizatidine, may be used instead, } \\
\text { Monitor benzodiazepine effect or } \\
\text { concentration }\end{array}$ \\
\hline $\begin{array}{l}\text { Dexamethasone (Corticosteroids) } \\
\text { Valium (Benzodiazepines) }\end{array}$ & $\begin{array}{c}\text { Pharmakokinetic } \\
\text { (increased metabolism) } \\
\text { CYP3A4 }\end{array}$ & Possible decreased midazolam effect & - \\
\hline $\begin{array}{c}\text { Alprazolam (Benzodiazepines) } \\
\text { Omeprazole }\end{array}$ & $\begin{array}{c}\text { Pharmakokinetic } \\
\text { (decreased metabolism) }\end{array}$ & $\begin{array}{l}\text { Possible diazepam, flurazepam, } \\
\text { clorazepate and triazolam toxicity }\end{array}$ & Monitor response to diazepam \\
\hline $\begin{array}{c}\text { Acetaminophen } \\
\text { Alprazolam (Benzodiazepines) }\end{array}$ & (mechanism not established) & Possible diazepam toxicity & Monitor clinical status \\
\hline $\begin{array}{c}\text { Alprazolam (Benzodiazepines) } \\
\text { Isoniazid }\end{array}$ & (decreased metabolism) & $\begin{array}{l}\text { Possible IV diazepam toxicity } \\
\text { Possible triazolam toxicity }\end{array}$ & $\begin{array}{l}\text { Decrease dosage, but in combined } \\
\text { anti-tuberculosis therapy, } \\
\text { suppression of diazepam effect by } \\
\text { rifampincin tends to predominate } \\
\text { Oxazepam metabolism not affected }\end{array}$ \\
\hline $\begin{array}{l}\text { Alprazolam (Benzodiazepines) } \\
\text { Piroxicam (Nonsteroidal anti- } \\
\text { inflammatory drugs) }\end{array}$ & $\begin{array}{c}\text { (delayed absorption) } \\
\text { (displacement from binding) }\end{array}$ & $\begin{array}{l}\text { Possible delayed onset of action of } \\
\text { naproxen with diazepam } \\
\text { Shortened induction with } \\
\text { midazolam anesthesia after aspirin }\end{array}$ & Monitor closely \\
\hline $\begin{array}{l}\text { Alprazolam (Benzodiazepines) } \\
\text { Rifampicin (Rifampin) }\end{array}$ & (increased metabolism) & $\begin{array}{l}\text { Possible decreased oral and IV } \\
\text { diazepam, triazolam or nitrazepam } \\
\text { effect and oral midazolam effect }\end{array}$ & $\begin{array}{l}\text { Increased dosage of benzodiazepine, } \\
\text { in combined anti-tuberculosis therapy } \\
\text { with isoniazid, effect of rifampincin } \\
\text { predominates; triazolam and oral } \\
\text { midazolam may be ineffective } \\
\text { in patients on rifampincin }\end{array}$ \\
\hline $\begin{array}{l}\text { Alprazolam (Benzodiazepines) } \\
\text { Dexamethasone (Corticosteroids) }\end{array}$ & $\begin{array}{l}\text { (probably increased } \\
\text { metabolism; CYP3A4) }\end{array}$ & Effect relatively small & Dose adjustment \\
\hline $\begin{array}{l}\text { Diazepam (Benzodiazepines) } \\
\text { Valium (Benzodiazepines) }\end{array}$ & Additive effects & Possible toxicity & Beaware of additive effects \\
\hline $\begin{array}{c}\text { Acetaminophen } \\
\text { Diazepam (Benzodiazepines) }\end{array}$ & (mechanism not established) & Possible diazepam toxicity & Monitor clinical status \\
\hline $\begin{array}{l}\text { Diazepam (Benzodiazepines) } \\
\text { Zantac (Antihistamines, H2- } \\
\text { blockers) }\end{array}$ & $\begin{array}{l}\text { (decreased metabolism) } \\
\text { (altered absorption) }\end{array}$ & $\begin{array}{l}\text { Possible benzodiazepine toxicity } \\
\text { with cimetidine } \\
\text { Altered benzodiazepine effect } \\
\text { with ranitidine }\end{array}$ & $\begin{array}{l}\text { Monitor clinical status } \\
\text { Monitor benzodiazepine effect or } \\
\text { concentration }\end{array}$ \\
\hline $\begin{array}{l}\text { Cipro (Fluoroquinolones) } \\
\text { Diazepam (Benzodiazepines) }\end{array}$ & (decreased metabolism) & $\begin{array}{l}\text { Possible diazepam toxicity with } \\
\text { ciprofloxacin }\end{array}$ & $\begin{array}{l}\text { Monitor clinical status } \\
\text { No effect of ciprofloxacin on } \\
\text { temazepam metabolism }\end{array}$ \\
\hline $\begin{array}{l}\text { Ampicillin (Penicillins) } \\
\text { Phenytoin }\end{array}$ & (displacement from binding) & $\begin{array}{l}\text { Possible increased phenytoin } \\
\text { toxicity with high-dose } \\
\text { intravenous Penicillin }\end{array}$ & Monitor clinical status \\
\hline $\begin{array}{l}\text { Decadron (Corticosteroids) } \\
\text { Valium (Benzodiazepines) }\end{array}$ & $\begin{array}{l}\text { (probably increased } \\
\text { metabolism; CYP3A4 }\end{array}$ & Possible decreased midazolam effect & Consider dose adjustment \\
\hline $\begin{array}{l}\text { Valium (Benzodiazepines) } \\
\text { Valproic acid (Valproate) }\end{array}$ & $\begin{array}{l}\text { (displacement from binding } \\
\text { and decreased metabolism- } \\
\text { glucuronidation) }\end{array}$ & $\begin{array}{l}\text { Possible IV diazepam toxicity } \\
\text { Possible midazolam toxicity }\end{array}$ & $\begin{array}{l}\text { Use IV diazepam with caution } \\
\text { Avoid concurrent use } \\
\text { Monitor midazolam } \\
\text { Monitor clinical status }\end{array}$ \\
\hline
\end{tabular}




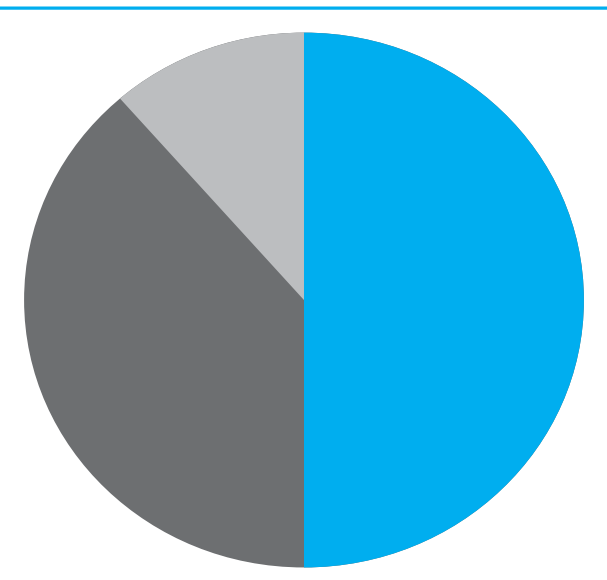

Total prescriptions

Prescription with drug interaction

Prescription without drug interaction

\section{Fig-1. Frequency of drug-drug interactions}

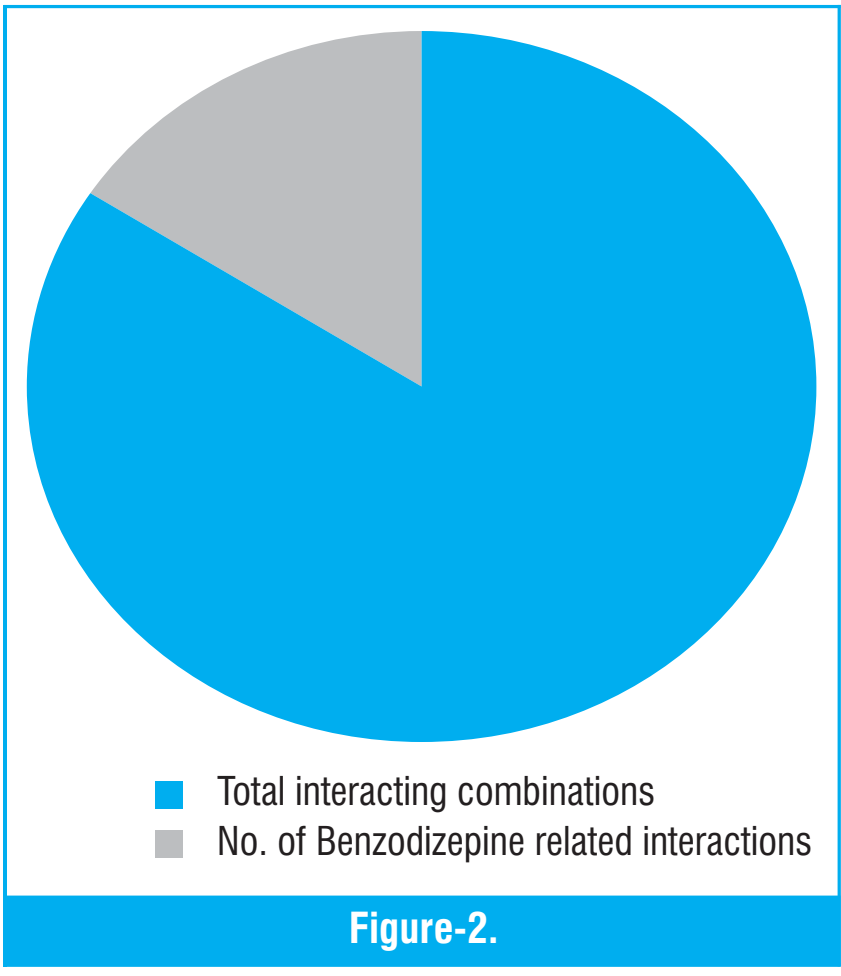

the condition of seriously ill patient, so they require alteration in therapy. This data shows that benzodiazepines and their derivatives are frequently prescribed to indoor patients. They are at higher risk of developing drug-drug interactions related to benzodiazepines. Benzodiazepines pointed out the action of assault epilepsy and emergencies. These are amongst the mainly constructive AEDs accessible for treating patients with position epilepticus or sensitive cyclic seizures. Additional faults comprise unpleasant events, such as sedation, drug interactions and cognitive impairment.

There are chances that benzodiazepines even at therapeutic doses may produce toxic effects or may become ineffective due to drug-drug interactions. Currently in Pakistan, hospitals are not equipped with drug interaction detecting software and the frequency of prevalence of drug interactions is very high. If this study is conducted on large scale in hospitals in Pakistan, more reliable results can be obtained.

\section{CONCLUSIONS}

The main outcomes of this study are that the frequent use of benzodiazepines can increase the percentage of drug interactions in indoor patients that can result in toxicity or ineffectiveness of the drug at therapeutic dose. Poly pharmacy in indoor patients in hospitals can result in moderate to severe drug interactions which require close monitoring to ensure patient safety. Patients in medical wards especially are using many medications at a time leading to DDIs. In order to minimize benzodiazepine toxicity in hospitalized patients, implementation of computerized software programs can help health care professionals in determining the risks of potential DDIs especially related to benzodiazepines.

Copyright@ 07 Jan, 2013.

\section{REFERENCES}

1. Hansten PD, Horn JR. Drug Interactions Analysis and Management, Facts \& Comparisons. Philadelphia, PA:Lippincott Williams\& Wilkins; 2009. ISBN: 10: 157439-311-8.

2. Becker ML, Kallewaard M, Caspers PW, Schalekamp T, Stricker BH. Potential determinants of drug-drug interaction associated dispensing in community pharmacies. Drug Saf. 2005;28:371-8. 
3. Linnarsson R. Drug interactions in primary health care: a retrospective database study and its implications for the design of a computerized decision support system. Scand J Prim Health Care. 1993;11:181-6.

4. Bergendal L, Friberg A, Schaffrath A. Potential drugdrug interactions in 5.125 mostly elderly out-patients in Gottenburg, Sweden. Pharm World Sci. 1995;17:152-7.

5. Merlo J, Liedholm H, Lindblad U, Bjorck-Linne A, Falt J, Lindberg G, et al. Prescriptions with potential drug interactions dispensed at Swedish pharmacies in January 1999: cross sectional study. BMJ. 2001;323(7310):427-8.

6. Colley CA, Lucas LM. Polypharmacy: the cure becomes the disease. J Gen Intern Med. 1993;8:278-83.

7. Bjerrum L, Andersen M, Petersen G, Kragstrup J. Exposure topotential drug interactions in primary health care. Scand J PrimHealth Care. 2003;21:153-8.

8. Jankel CA, Fitterman LK. Epidemiology of drug-drug interactions as a cause of hospital admissions. Drug Saf. 1993;9:51-9.

9. Huic M, Mucolic V, Vrhovac B, Francetic I, Bakran I, GiljanovicS. Adverse drug reactions resulting in hospital admission. Int $\mathrm{J}$ Clin Pharmacol Ther. 1994;32:675-82.

10. McDonnell PJ, Jacobs MR. Hospital admissions resulting from preventable adverse drug reactions. Ann Pharmacother. 2002;36:1331-6.

11. Peyriere H, Cassan S, Floutard E, Riviere S, Blayac JP, Hillaire-Buys D, et al. Adverse drug events associated with hospital admission. Ann Pharmacother. 2003;37:5-11.

12. Becker ML, Caspers PW, Kallewaard M, Bruinink RJ, KylstraNB, Heisterkamp S, et al. Determinants of potential drug-druginteraction associated dispensing in community pharmacies in the Netherlands. Pharm World Sci. 2007;29:51-7.

13. Abarca J, Colon LR, Wang VS, Malone DC, Murphy JE,
Armstrong EP. Evaluation of the performance of drugdrug interaction screening software in community and hospital pharmacies. JManag Care Pharm. 2006;12:383-9.

14. Glassman PA, Simon B, Belperio P, Lanto A. Improving recognition of drug interactions: benefits and barriers to using automated drug alerts. Med Care. 2002;40:1161-71.

15. Tzimis L, Katsantonis N, Leledaki A, Vasilomanolakis K, Kafatos $A$. Prescribed medication and nutrition of social carepatients in Crete, Greece. Public Health. 1996;110:361-7.

16. Tzimis L, Katsantonis N, Leledaki A, Vasilomanolakis K, Kafatos A. Antibiotics prescription for indigent patients in primary care. J Clin Pharm Ther. 1997;22:227-35.

17. Tzimis L, Kafatos A. Drug utilization and health behaviours among indigent elderly patients in Crete, Greece. Pharmacoepidemiol Drug Saf. 1999;8: 105-14.

18. Antonakis N, Xylouri I, Alexandrakis M, Cavoura C, Lionis C. Seeking prescribing patterns in rural Crete: a pharmacoepidemiological study from a primary care area. Rural Remote Health.2006;6:488.

19. Hansten PD, Horn JR. The top $\mathbf{1 0 0}$ drug interactions: a guide to patient management. Freeland, WA: $\mathrm{H}$ \& $\mathrm{H}$ Publications. LLP;2009.ISBN 978-0-9819440-0-5.

20. Hansten PD, Horn JR. Drug interactions \& updates. 7th ed. Vancouver, WA: Applied Therapeutics Inc.; 1992. ISBN-10: 0-8121-1381-0.

21. Astrand B, Montelius E, Petersson G, Ekedahl A. Assessment of Prescription quality: an observational study at three mail-order pharmacies. BMC Med Inform DecisMak. 2009:9:8.

22. Murphy JE, Malone DC, Olson BM, Grizzle AJ, Armstrong EP, Skrepnek GH. Development of computerized alerts with management strategies for 25 serious drug-drug interactions. Am J Health Syst Pharm. 2009;66:38-44.

23. Cusack CM. Electronic health records and electronic prescribing: promise and pitfalls. Obstet Gynecol Clin 
North Am. 2008:35:63-79.

24. Jani YH, Ghaleb MA, Marks SD, Cope J, Barber N, Wong IC. Electronic prescribing reduced prescribing errors in a pediatricrenal outpatient clinic. J Pediatr. 2008;152:214-8.

25. Rupp MT, Warholak TL. Evaluation of e-prescribing in chain community pharmacy: best-practice recommendations. J AmPharm Assoc. 2008;48: 364-70.

26. Venkatraman R, Durai R. Errors in medicine administration: how can they be minimized? J Perioper Pract. 2008;18:249-53.
27. Carroll NV. Do community pharmacists influence prescribing? J Am Pharm Assoc. 2003;43:612-21.

28. Tamblyn R, Huang A, Perreault R, Jacques A, Roy D, Hanley J, et al. The medical office of the 21st century (MOXXI): effectiveness of computerized decisionmaking support.

29. Vonbach P, Dubied A, Krahenbuhl S, Beer JH. Evaluation of frequently used drug interaction screening programs. Pharm World Sci. 2008;30: 367-74.

\section{AUTHOR(S):}

1. DR. SYED TALAT IQBAL

Department of Forensic Science, Nawaz Sharif Medical College, University of Gujrat

2. DR. ZAINAB BATOOL

Department of Pharmacology,

Nawaz Sharif Medical College, University of Gujrat

3. DR. SAJID MEHMOOD

Department of Biochemistry and Molecular Biology, Nawaz Sharif Medical College, University of Gujrat

\section{Correspondence Address:}

\section{Dr. Sajid Mehmood}

Department of Biochemistry and Molecular Biology, Nawaz Sharif Medical College, University of Gujrat sajid.mehmood@uog.edu.pk

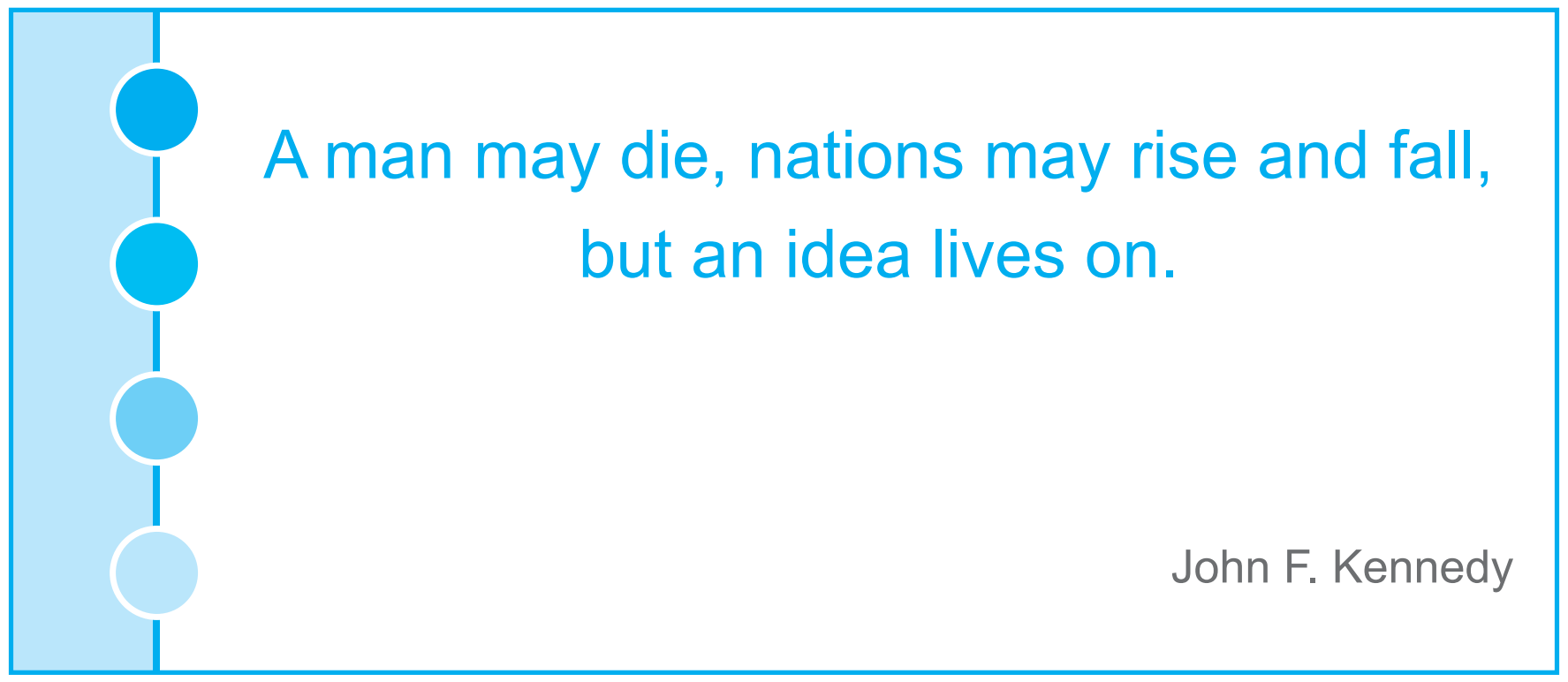

